\title{
Solar Forcing of Global Climate Change
}

\author{
By P A UL E. DAMON AND JOHN L. JIRIKOWIC
}

Department of Geosciences, University of Arizona, Tucson, AZ 87521, USA

Using present global warming and paleoclimatic records from climatically sensitive regions as a frame of reference, we infer that global temperature changes did not exceed $\pm 0.5^{\circ} \mathrm{C}$ during the current interglacial or $\pm 2.0^{\circ} \mathrm{C}$ during the last glacial period. In order to completely explain such fluctuations by solar irradiance changes, all solar and terrestrial factors must be optimized. Since this is unlikely, we conclude that solar forcing of pre-anthropogenic climate change is a significant and perhaps dominant factor but other processes must also be significant. Solar irradiance changes alone cannot result in the temperature decrease required to change from interglacial to glacial as suggested by Opik (1965).

\section{Introduction}

\subsection{Glacial and interglacial climate}

During the Pleistocene (1.8 Ma to present), the Earth's climate has varied between two states, glacial and interglacial. This can be seen in the oxygen isotope stratigraphy in Figure 1. The meteorological cycle has been likened to a multiple-stage still with 6 to 7 theoretical distillation plates (Epstein 1958). The amount of fractionation in the hemispheric distillation process is a function of altitude, latitude and temperature gradient from equatorial to polar regions. The variations of the ${ }^{18} \mathrm{O} /{ }^{16} \mathrm{O}$ ratio during the hydrologic cycle are measured in \%o relative to mean seawater. With reference to the Byrd core, Antarctica, it can be seen that $\delta^{18} \mathrm{O}$ fluctuates around $-40 \%$ from about $110 \mathrm{ka}$ to $18 \mathrm{ka}$, gradually increasing after $18 \mathrm{ka}$ to fluctuate around a new steady-state, $-34 \%$, from about $10 \mathrm{ka}$ to present. The increase in $\delta^{18} \mathrm{O}$ from $-40 \%$ to $-34 \%$ is the result of global warming and coincident with rising sea-level as the continental ice masses melted (Fairbanks 1989). The Camp Century, Greenland core shows $\delta^{18} \mathrm{O}$ variation around the same two steady states but during the transition form $18 \mathrm{ka}$ to $10 \mathrm{ka}$, the warming is temporarily interrupted by a return to glacial conditions during the Younger Dryas from about $12,900 \mathrm{BP}$ to $11,600 \mathrm{BP}$. Thus, the hydrologic cycle is responding to both regional and global climate changes. The North Atlantic is more sensitive to climate change during the glacial period as can be seen by the larger fluctuations of $\delta^{18} \mathrm{O}$ in Greenland ice cores when compared to Antarctic ice cores but the two states are global in nature. In general, global climate during the Pleistocene can be modeled as a set of systems fluctuating around the glacial and interglacial steady states separated by transitional episodes. $\delta^{18} \mathrm{O}$ fluctuations around steady state are three to four times less during the interglacial compared to the glacial epoch.

\subsection{Regional vs. global climate change}

According to estimates from the CLIMAP project (CLIMAP Project Members, 1981), the Laurentides ice mass reached a thickness of $3800 \mathrm{~m}$ and the northwestern European ice mass reached a thickness of $2500 \mathrm{~m}$, whereas the Greenland ice cap reached an intermediate thickness of about $3200 \mathrm{~m}$. Using an empirical equation from Dansgaard (1964), we can estimate the glacial age temperature at Camp Century to have been $\approx-38^{\circ} \mathrm{C}$. The Northern Hemisphere continental areas covered by ice must have been at similar temperatures, warming to their present annual temperatures. As a robust 

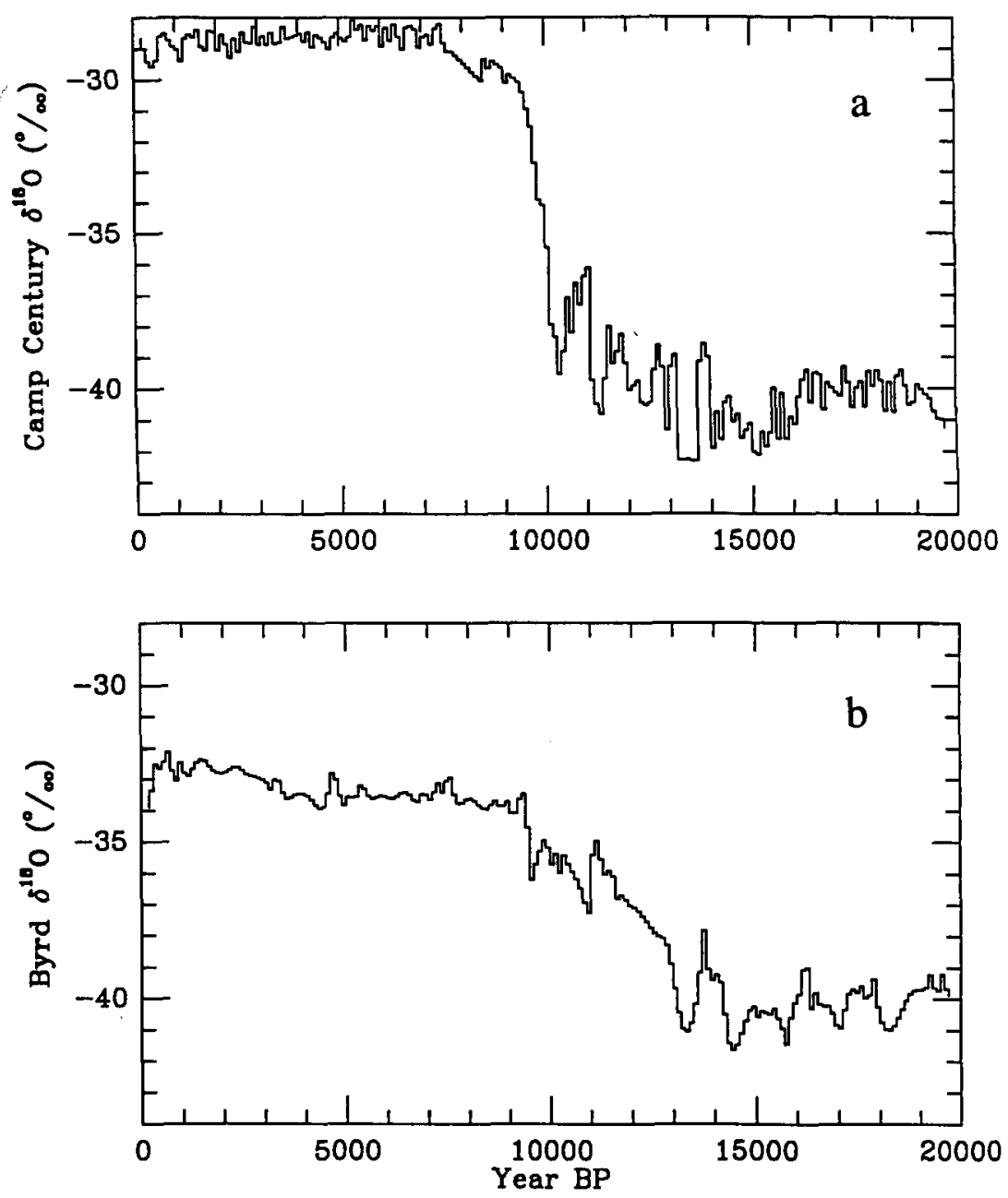

Figure 1. Ice core $\delta^{18} \mathrm{O}$ (Camp Century, Greenland, after Dansgaard et al. 1982 (1a); Byrd Station, Antarctica, after Johnsen et al. 1972, (1b)). Note that both isotopic records show distinct modes between glacial and interglacial states. For the glacial state (20 ka-13 ka), $\delta^{18} \mathrm{O}$ varies by an amplitude of $2 \%$ on a century time-scale about an average value of $\approx-40 \%$. During the interglacial ( 9 ka-present), $\delta^{18} \mathrm{O}$ varies by an amplitude of $<0.5 \% 0$ around an average of $\approx-29 \%$ o for Camp Century and $\approx-33 \%$ for Byrd Station. The decreased $\delta^{18} \mathrm{O}$ variability suggests a decrease in sensitivity to climate forcings. Camp Century shows greater glacial to interglacial contrast due the influence of surface ice and snow expanse during the glacial period. A sharp increase in the Camp Century record contrasts with the more gradual increase in the Byrd Station record. This may reflect the ameliorating influence of the Southern Ocean. The pronounced Younger Dryas negative deflection $(\approx 10.5 \mathrm{ka})$ present in the Camp Century may correlate with a much smaller feature $(\approx 10 \mathrm{ka})$ in the Byrd Station record (calibrated ages are about 1700 years older as in the text). The Younger Dryas event may have affected North Atlantic circulation greatest and thus adjacent continental indicators have more profound signatures. Thus, $\delta^{18} \mathrm{O}$ records contain both global and region climate signals. 


$\begin{array}{lcc}\text { Region } & \Delta T\left({ }^{\circ} \mathrm{C}\right) & \text { Area of Globe (\%) } \\ \text { Presently Glaciated } & -10 & 3 \\ \text { Not glaciated at present } & -40 & 5.7 \\ \text { Other continental areas } & -6 & 20.5 \\ \text { The world oceans } & -2.3 & 70.8 \\ \text { Hansen } \text { et al., 1984 } & & \\ \text { GCM Model: } & & \end{array}$

Contribution to Global
Mean weighted by area $\left({ }^{\circ} \mathrm{C}\right)$
-0.3
-2.3
-1.2
-1.6
$\Sigma=-5.4$
$\Sigma=-5.3$

TABLE 1. Temperature changes $(\Delta T)$ from present to $18 \mathrm{ka}$.

but not rigorous estimate of the temperature increase for those areas, we suggest about $40^{\circ} \mathrm{C}$. For the areas still covered by polar ice, we estimate a change of about $10^{\circ} \mathrm{C}$. From a paleoclimatology summary by Crowley \& North (1991), we take the average change at mid-latitudes to be between $5-8^{\circ} \mathrm{C}$ and $4-5^{\circ} \mathrm{C}$ for tropical continent and areas under the influence of maritime air masses. Let us assume an average of $\approx 6^{\circ} \mathrm{C}$ for continental areas not covered by ice sheets. CLIMAP Project (McIntyre et al. 1976) estimated an average change for the global oceans of only $2.3^{\circ} \mathrm{C}$ but with great variation between different ocean basins. For example, in the Northern Hemisphere, they estimated temperature changes varied from $0.8^{\circ} \mathrm{C}$ for the Indian Ocean to $3.8^{\circ} \mathrm{C}$ for the North Atlantic. We summarize and weight these changes by areas in Table 1 , arriving at a global change of $-5.4^{\circ} \mathrm{C}$ from the glacial to the present state. This compares favorably with more rigorous GCM (global circulation model) modeling by Hansen et al. (1984) and serves to illustrate several pertinent points. First, the global oceans serve as a great source and sink of heat moderating climate. Second, $8.7 \%$ of the area of the Earth accounts for $\approx 50 \%$ of the global warming during the transition from glacial to interglacial states. Third, there were large regional differences in temperature changes around the global mean.

As previously noted, oxygen isotope stratigraphy demonstrates that the hemispheric temperature fluctuations during the past 10,000 years (the Holocene) are relatively small. The linear empirical relationship between $\delta^{18} \mathrm{O}$ and temperature (Bradley 1985) suggests that these fluctuations do not exceed $\pm 0.6^{\circ} \mathrm{C}$ (or $1.2^{\circ} \mathrm{C}$ peak-to-peak). If this is correct, global warming during the past 100 years of $0.5^{\circ} \mathrm{C}$ based on instrumental records (Folland et al. 1990) should be a very significant event relative to previous events during the Holocene. Of course, regional temperature variations of sub-hemispheric scale have been both lesser and greater. For example, there was an insignificant increase in temperature during the last century for the contiguous United States comprising roughly $1.6 \%$ of global area (Hanson et al. 1989). However, from data in Trends, 1991 (Boden et al. $1991)$, we calculate an increase of $(1.2 \pm 0.2)^{\circ} \mathrm{C}(\mathrm{s})$ from solar cycle 14 (1901-1913) to solar cycle 21 (1976-1987) for the southern deserts which is one of 23 regions of the U.S.A. reported in Trends, 1991. These sorts of regional variations of climate change together with conceptual and dating problems make it difficult to evaluate past changes in Holocene global temperatures. The instrumental record coupled with GCM studies can be helpful in resolving this problem. Specifically, in order to evaluate the feasibility of solar forcing of global climate, we need to know the magnitude of global Holocene temperature changes to be forced. As noted above, oxygen isotope studies of polar ice suggest global changes equal to or less than $\pm 0.6^{\circ} \mathrm{C}$ during the Holocene. This suggestion needs further justification.

GCM studies suggest that global temperature change will be greatest at high altitudes 
and high continental latitudes (Wang et al. 1991). High altitude temperatures are governed by evaporation of surface ocean water with transfer of 540 calories per gram of latent heat to higher latitudes. Albedo changes, as the result of changes in the ice and snow cover, produce high-latitude continental sensitivity to global climate forcing. Evidence for climatic events like the Medieval Warm Epoch and Little Ice Age come from North Atlantic border-lands and Europe above $45^{\circ} \mathrm{N}$. It has been possible recently to demonstrate by study of montane glaciers that these climatic events are global rather than merely regional in scope (Rothlisberger 1986). Montane glaciers also provide perspective concerning the relative intensity of 20th Century global warming.

Hasenrath \& Kruss (1992) have compared glacial maps for Mount Kenya (elevation 4.6 to $5 \mathrm{~km}$ ). They estimate that the Mount Kenya Glacier retreated by $40 \%$ in area from 1963 to 1987 . The retreat of the terminus of the Speke Glacier in the Ruwenzori Range of Uganda has accelerated from an average of $\approx 2 \mathrm{~m} / \mathrm{yr}$ between 1958 and 1977 to more than $11 \mathrm{~m} /$ yr between 1977 and 1990 (Kaser \& Noggler 1991). The areal extent of worldwide montane glaciation has been reduced by about $50 \%$ during the last century (Thompson 1991). Thompson et al. (1989) have studied the Dunde Ice Cap on the Qinghai-Tibetan Plateau at a summit elevation of $5235 \mathrm{~m}$. According to these authors, in that region "the last 60 years were apparently one of the warmest periods in the entire record, equaling levels of the Holocene maximum between 6000 and 8000 years ago" (p. 474).

Evidence for high-latitude warming comes from dendroclimatologic studies and measurements of the temperature gradients in bore holes. Innes (1991) has documented highaltitude and high-latitude increases in 20th Century tree growth from about 30 studies of trees from Northern Europe and North America. In contrast to Thompson's conclusion, Innes states, "It appears that neither the northern extent nor the present growth rates of boreal forests have reached the extent of rates characteristic of the mid-Holocene, when the climate was demonstrably warmer." However, from their dendroclimatologic study of high-latitude boreal sites in Canada and Alaska, Jacoby \& Arrigo (1989) conclude that "the global warming trend over the past century of increasing $\mathrm{CO}_{2}$ has exceeded the recent (past three centuries) level of natural variability (pre-anthropogenic) of the climate system". In a study of old-growth Huon pines from a sub-alpine site in western Tasmania, Cook et al. (1992) concluded that, "Although the most recent 25-year period is warmer than any comparable period over the past 1090 years, it is not yet statistically unprecedented" (p. 215). Graybill \& Shiyatov (1992) have reconstructed June-July temperatures for ad 961-1969 using tree-ring width variation of Siberian Larch from the Polar Urals $\left(65-67^{\circ} \mathrm{N}\right)$. They concluded that "the relatively sustained rise in temperature from the 1880 s to the 1960 s has the greatest magnitude in the record for such an extended period $\left(1.6^{\circ} \mathrm{C}\right.$ difference between the 20-year intervals centered on 1870 and 1960)" (p. 411). Note that for this climate sensitive area, this recent regional warming event is threefold greater than 20 th Century global warming of $\approx 0.5^{\circ} \mathrm{C}$. Bore hole temperature gradients from Central and Eastern Canada (Beltrami et al. 1992; Shen \& Beck 1992; Wang et al. 1992) as well as from the Alaskan Arctic (Lachenbruch \& Vaughn 1986; Kakuta 1992) confirm the temperature rise from the late 19th Century through the late 20th Century. The temperature rise in Canada was typically $1-3^{\circ} \mathrm{C}$ and greater at Prudhoe Bay, Alaska where Kakuta (1992) estimates warming by $4^{\circ} \mathrm{C}$ from ad 1853 to ad 1973.

Summarizing, the modern instrumental record has made it possible to estimate 20th Century global warming of about $0.5^{\circ} \mathrm{C}$ (Folland et al. 1990). There is insufficient data to establish directly global climate change prior to the 19 th Century. The existing data is biased toward relatively high-latitude, climatically-sensitive regions of the North Atlantic. 
However, our comparison of the recent warming event with the paleoclimate record within climatically-sensitive regions suggests that this recent event exceeds in intensity natural global climate variability during the last millennium and is of comparable magnitude to the Holocene maximum between 6000 and 8000 years ago. Oxygen isotope stratigraphy also demonstrates the relative global stability of pre-anthropogenic climate. Solar forcing needs only account for global temperature variations of no more than $\pm 0.5^{\circ} \mathrm{C}$ to account for all the natural climate variability during the last millennium. The Holocene maximum may exceed a global temperature increase of $\pm 0.5^{\circ} \mathrm{C}$. However, our previous estimate of $\pm 0.6^{\circ} \mathrm{C}$ variability from the polar oxygen isotope record is probably a conservative upper limit for global temperature change during the Holocene.

\section{Solar forcing of Holocene climate}

\subsection{The Sun as a low-frequency harmonic oscillator}

The production of cosmogenic ${ }^{14} \mathrm{C}$ is modulated by solar activity via the magnetic field associated with the solar wind. The relationship is inverse and, so, the various historically observed solar minima such as the Maunder Minimum occur as ${ }^{14} \mathrm{C}$ maxima and the Medieval Solar Maximum from ad 1100-1250 occurs as a ${ }^{14} \mathrm{C}$ minimum in the spectrum of ${ }^{14} \mathrm{C}$ variations. The reader may refer to two papers for recent reviews of the subject (Damon \& Sonett 1991; Stuiver et al. 1991). Damon \& Sonett (1991) concluded that medium- and short-term variations with periods of $\approx 208$ (Suess), 88 (Gleissberg), and 11 (Schwabe) years are in large part produced by solar wind modulation. A longer period of $\approx 2300$ years (Hallstattzeit) seemed enigmatic but appears to $100 \%$ amplitude modulate the Suess cycle. The $\approx 2300$-year period seems to be associated with recurrent Little Ice Ages (Schmidt \& Gruhle 1988). Stuiver \& Braziunas (1991), using the maximum entropy spectral method (MEM), chose a 420-year period as a fundamental with harmonics related to changes in the solar convective zone and noted that it splits into three periods at higher AR order. We note that the apparent splitting is an artifact of the MEM method. The peaks are always present but vary greatly with the autoregressive (AR) order. Too low an AR order results in oversmoothing. We deduced from both DFT and MEM power spectral analyses that the four periods $(526,424,356$ and 300 years) are the 4, 5, 6, 7 harmonics of the poorly resolved Hallstattzeit period that we estimated from its harmonics to be 2120 years (Damon \& Jirikowic 1992a,b). Further analysis yielded 212 years for the Suess period with strong ( $\geq 95 \%$ confidence) harmonics at 106 years (2nd harmonic) and 53 years (4th harmonic).

The harmonics of the Suess period combined with the Gleissberg period appear to strongly modulate the 11.1-year (Schwabe) cycle. Furthermore, a reasonable fit to the annual Wolf Sunspot Indices can be obtained using a squared amplitude modulation model (after Sonett 1982) by allowing these periods $(212,106,53,88.3$ years) to amplitude modulate the 11.1-year carrier (Damon \& Jirikowic 1992a).

Subsequent to the work summarized above, one of the authors (Jirikowic) added Thomson's (1990) multi-taper power spectral analysis technique to the techniques made available to us by Prof. Charles Sonett here at the University of Arizona (periodogram, Bretthorst-Bayesian, Maximum Entropy [MEM], Discrete Fourier Transform [DFT]). The analysis of the latest version of the high-precision ${ }^{14} \mathrm{C}$ data set (Stuiver \& Reimer 1993) is shown in Figure 2. The Hallstattzeit fundamental and first nine overtones (2$10 \mathrm{f}_{\mathrm{H}}$ ) clearly resolve at $\geq 95 \%$ confidence (harmonic $\mathrm{F}$-test). The Suess period ( $\mathrm{f}_{\mathrm{S}}$ and $10 \mathrm{f}_{\mathrm{H}}$ ) has unusually high power spectral density and appears to act as a fundamental as well as a harmonic of the Hallstattzeit. The accounts for the high spectral power 


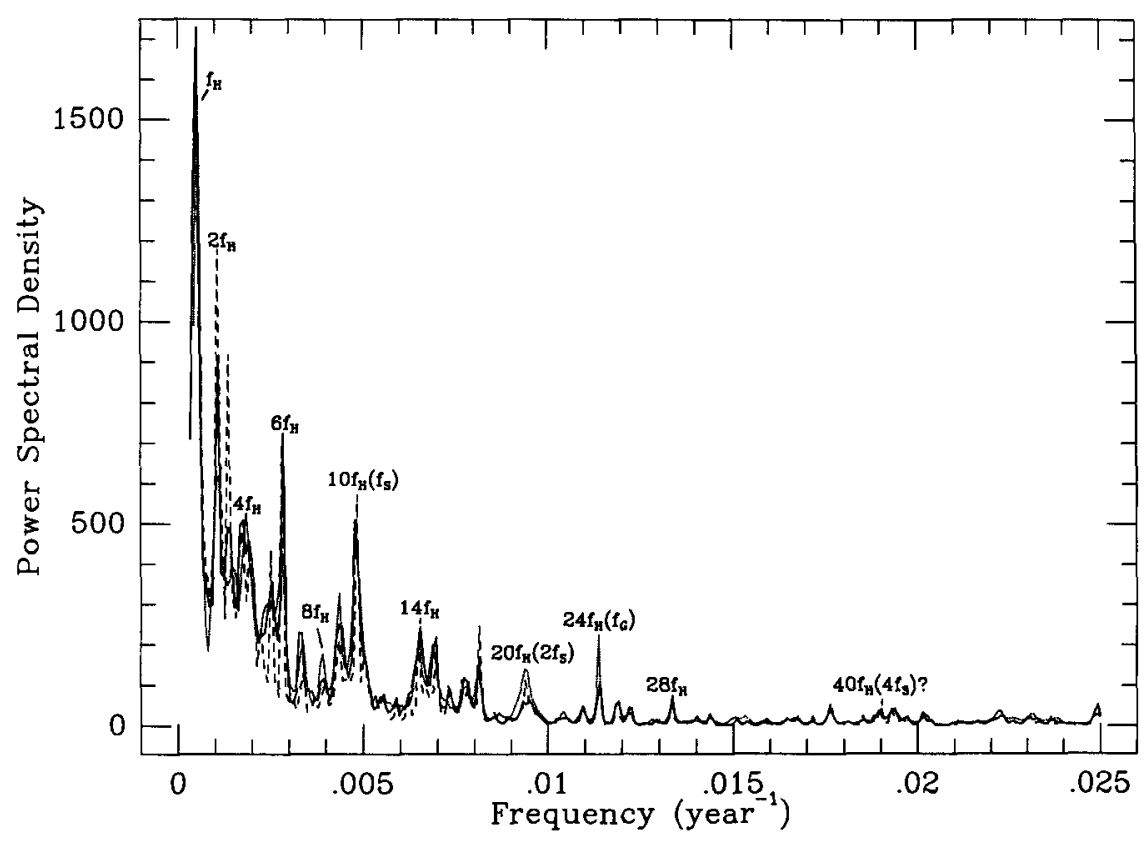

Figure 2. Power spectral density estimates using Thomson's Multi-taper Method (Thomson 1990) and three autoregressive modeling orders: 120 (dotted), 160 (solid) and 200 (dashed) from the 1993 Radiocarbon Calibration tree-ring $\delta^{14} \mathrm{C}$ data (Stuiver \& Reimer 1993). Annotated peaks show assignment to hypothetical harmonics to the fundamental Hallstattzeit (subscript H), Suess (subscript S) and Gleissberg (subscript G) variations. All these peaks have greater than $95 \% \mathrm{~F}$-test confidence. Although the Hallstattzeit is poorly resolved, the annotated harmonics combine to suggest a fundamental period of $2108 \pm 15$ years. Earlier spectral analyses (Damon \& Jirikowic 1992b) showed a strong fourth harmonic of the Suess that is not apparent here.

spectral density of its second harmonic $\left(2 \mathrm{f}_{\mathrm{S}}, \geq 95 \%\right.$ confidence $)$. However, its fourth harmonic appears as a relatively weak doublet, unlike the MEM and DFT techniques ( $\geq 95 \%$ confidence). The Gleissberg period is prominent at $\geq 95 \%$ confidence ( 88.1 years).

Neglecting the poorly resolved second Hallstattzeit harmonic but using harmonics 3-10 plus $14,15,17,18$ (all with $\geq 95 \%$ confidence) to calculate the Hallstattzeit fundamental, we obtain $2108 \pm 15$ ( $\bar{\sigma}$ years compared with $2115 \pm 18(\bar{\sigma})$ years previously obtained using the combined MEM and DFT methods (Damon \& Jirikowic 1992b).

The enigmatic Hallstattzeit period may be divided into two episodes. For $\approx 1520$ years, it is associated with high solar activity and weak periodicity followed by $a \approx 600$ year episode in which solar activity is low on the average and the Suess period and its harmonics as well as the Gleissberg period are strong. These 600-year episodes are associated with Little Ice Ages. Thus, when the Medieval Solar Maximum ended at ad 1250, the Little Ice Age began accompanied by a series of profound solar minima and terminated after about 600 years toward the middle of the 19th Century when the Modern Solar Maximum began (Jirikowic \& Damon 1994).

Instrumental analysis has confirmed a significant change in solar irradiance of $0.1 \%$ during the 21st solar cycle (Willson \& Hudson 1988, 1991). Paleoclimate data suggests 


\begin{tabular}{|c|c|c|c|c|c|}
\hline $\begin{array}{l}\text { Solar } \\
\text { Condition }\end{array}$ & $\begin{array}{l}\text { Change in } \\
\text { Solar } \\
{ }^{1} \\
\text { Irradiance }\end{array}$ & $\begin{array}{c}\Delta \text { Forcing } \\
\text { (tropopause } \\
\text { level) }\end{array}$ & $\begin{array}{c}\Delta T_{\mathrm{eq}}\left({ }^{\circ} \mathrm{C}\right) \\
\mathrm{Glacial}^{2} \\
2.4^{\circ} \mathrm{C}\end{array}$ & $\begin{array}{c}\Delta T_{\text {eq }}\left({ }^{\circ} \mathrm{C}\right) \\
\text { Present Glacial } \\
1.0^{\circ} \mathrm{C}\end{array}$ & $\begin{array}{c}\Delta T_{\text {eq }}\left({ }^{\circ} \mathrm{C}\right) \\
\text { Future }^{3} \\
0.6^{\circ} \mathrm{C}\end{array}$ \\
\hline $\begin{array}{l}\text { Present Sun } \\
\text { AD 1980-1986 }\end{array}$ & 0.0 & 0.0 & 0.0 & 0.0 & 0.0 \\
\hline $\begin{array}{l}\text { No plage, spots } \\
\text { or network }\end{array}$ & -1.5 & -0.36 & -0.9 & -0.4 & -0.2 \\
\hline $\begin{array}{l}\text { No-cycling stars } \\
\text { (average) }\end{array}$ & -2.4 & -0.58 & -1.4 & -0.6 & -0.3 \\
\hline $\begin{array}{l}\text { Minimum possible } \\
\text { Sun }\end{array}$ & -3.5 & -0.84 & -2.0 & -0.8 & -0.5 \\
\hline
\end{tabular}

TABLE 2. Decreasing equilibrium temperature $\left(T_{\mathrm{eq}}\right)$ as a function of solar condition.

that longer periods such as the Hallstattzeit, Suess and Gleissberg periods may also be associated with changes in solar irradiance (e.g., see Eddy 1977). Further evidence comes from solar and astrophysics.

\subsection{The Sun as a variable star}

As discussed elsewhere in this colloquium's proceedings (see Lockwood 1994), 74 solartype stars have been observed at the Mount Wilson Observatory. Of these 74, 13 have been studied monthly since 1966 and nightly since 1980 (Baliunas \& Jastrow, 1990). Only sporadic measurements were made since 1978 for the other 61 stars. Nine of the 13 stars were observed to show a range of magnetic activity similar to the solar cycle whereas four that showed no variation of magnetic activity with time were assumed to be analogous to the Sun during the Maunder and other solar minimum. The nine magnetically active stars had regular activity cycles like the Sun. Their brightness varied by up to $0.4 \%$ compared to $0.1 \%$ for the Sun during cycle 21 . Baliunas \& Jastrow (1990) state, "Our results suggest that when a solar-type star enters or leaves a Maunder Minimum, its brightness may change by more that the $0.1 \%$ observed during the Sun's 11-year cycle" (p. 522). Lockwood et al. (1992) presented a compilation of eight years of observations of 33 stars at the Lowell Observatory. They report that the stars whose mean activities were closest to the Sun's varied in brightness by 2.5 to 10 times the variation in brightness of the Sun. They state, "This raises the question of whether the Sun's cycle irradiance variation is always so small or whether larger changes occur in other cycles or over longer time intervals" (p. 655).

\subsection{Solar variability and the Maunder Minimum}

Based on current knowledge of the Sun and Sun-like stars, Lean et al. (1992) estimated the change in solar irradiance and forcing at the top of the atmosphere for various conditions of the Sun (see Table 2). Assuming, as did Baliunas \& Jastrow (1990), that the Maunder Minimum was equivalent in change of irradiance to the average solar-like noncycling stars yields a 2.4 change in irradiance. Also, assuming that a global equilibrium temperature decrease of $1^{\circ} \mathrm{C}$ was required to explain Little Ice Age cooling, they conclude, "... that solar forcing may have contributed some, but not all, of the observed warming from the Little Ice Age to the present time" (p. 1594).

Keeping in mind that the $\approx 0.5^{\circ} \mathrm{C}$ rise in temperature in recent time began from a 


$\begin{array}{lcc}\text { Feedback } & \text { Gain } & \Delta T\left({ }^{\circ} \mathrm{C}\right) \\ \text { Unity } & 0 & -0.6 \\ \text { Water vapor-clouds } & 0.415 & -2.2 \\ \text { Land ice } & 0.169 & -0.9 \\ \text { Sea ice } & 0.132 & -0.7 \\ \text { Vegetation } & 0.057 & -0.3 \\ \mathrm{CO}_{2} & 0.113 & -0.6 \\ & \sum g_{i}=0.886 & \sum \Delta T_{\text {eq }}=-5.3\end{array}$

TABLE 3. Gains $\left(g_{i}\right)$ and temperature increments resulting from feedbacks at the Ice Age Maximum (18 ka).

relatively cool global temperature in the late 19 th Century, and this rise approaches or exceeds previous such warming events during the Holocene (see 1.2 above), we suggest that the estimate of $1{ }^{\circ} \mathrm{C}$ decrease in global cooling exceeds what is required to explain the Little Ice Age cooling during the Maunder Minimum. We concluded that less than $\pm 0.5^{\circ} \mathrm{C}$ global cooling is required to explain climate variability during the last millennium. The global temperature rise from the Maunder Minimum to ad 1980-1986, based on the paleoclimatic record and instrumental measurements discussed, is greater than $0.5^{\circ} \mathrm{C}$ but less than $1^{\circ} \mathrm{C}$.

In order to evaluate the temperature decrease resulting from a given change in solar irradiance (Table 2), various positive feedbacks must be considered. For our analyses, we refer to Hansen et al. (1984). Their paper included analysis of the various gains $\left(g_{i}\right)$ and temperature increments $\left(\Delta T_{i}\right)$ including those for water vapor-clouds, land ice, sea ice, vegetation, and $\mathrm{CO}_{2}$ (see Table 3 ).

From Table 3 , the equilibrium temperature change, $\Delta T_{\mathrm{eq}}=5.3^{\circ} \mathrm{C}$ and the temperature increment that would occur without feedbacks, $\Delta T_{0}=0.6^{\circ} \mathrm{C}$. The total feedbacks, $\sum f_{i}$ is related to the total gain, $\sum g_{i}$, by:

$$
\sum_{i} f_{i}=\frac{1}{1-\sum_{i} g_{i}}=\frac{1}{1-0.886}=8.8
$$

and $\Delta T_{0}$ is related to $\Delta T_{\mathrm{eq}}$ by:

$$
\Delta T_{0}=\frac{\Delta T_{\text {eq }}}{\sum_{i} f_{i}}=\frac{5.3^{\circ} \mathrm{C}}{8.8}=0.6^{\circ} \mathrm{C}
$$

The relative increment in solar energy required to yield the increment $\Delta T_{0}$ is:

$$
\frac{\Delta S_{0}}{S_{0}}=4 \frac{\Delta T_{0}}{T_{\text {eq }}}=\frac{4 \times 0.6^{\circ} \mathrm{K}}{255^{\circ} \mathrm{K}}=9.4 \times 10^{-3}
$$

Note that the surface temperature of Earth is warmer by $\approx 33^{\circ} \mathrm{K}$ due primarily to the greenhouse gases. The change in solar energy required to obtain $\Delta T_{0}$ is

$$
9.4 \times 10^{-3} \times 1367.54 \mathrm{Wm}^{-2}=12.8 \mathrm{Wm}^{-2}
$$

that corresponds to a forcing at the tropopause level of $12.8 \mathrm{Wm}^{-2} \div 5.7$ or $2.2 \mathrm{Wm}^{-2}$. This yields a climate sensitivity of $5.3 / 2.2 \mathrm{Wm}^{-2}=2.4^{\circ} \mathrm{C} / \mathrm{Wm}^{-2}$.

Likewise, Hansen et al. (1984) estimate $\sum f_{i}$ at present to be 3 to 4 , we take $f \approx 3.6$ that yields a climate sensitivity of $1^{\circ} \mathrm{C} / \mathrm{Wm}^{-2}$. If we assume in a world without ice, albedo effects are negligible, the temperature increase required to attain an ice-free state 


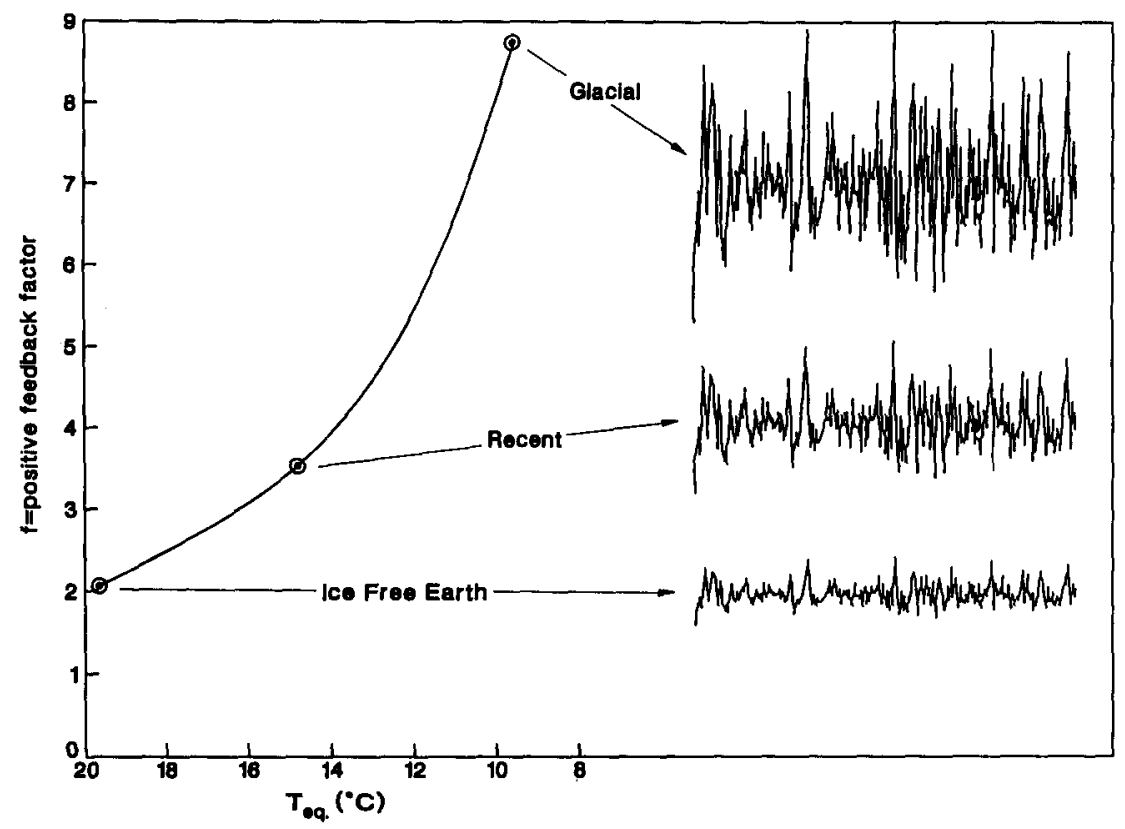

FIgURE 3. The relation between equilibrium surface temperature $\left(T_{\text {eq }}\right)$, positive feedbacks $\left(\sum f_{i}\right)$ and climate sensitivity. As a consequence of the increased positive feedbacks in colder climates, the same change in solar energy would have the greatest effect during glacial epochs and the least effect for an ice-free Earth.

would be a minimum of $4.8^{\circ} \mathrm{C}$ (Barron \& Washington 1984), the sum of feedbacks would be 2.1 and the climate sensitivity would be $\approx 0.6^{\circ} \mathrm{C} / \mathrm{Wm}^{-2}$.

In order to go from the present climate to an ice-free (swamp-ocean) climate requires a forcing at the tropopause level of $8.6 / \mathrm{Wm}^{-2}$ or an increase of $3.5 \%$ in the solar constant whereas a cooling from present to the climax of the last ice age at 18 ka requires only a forcing decrease of $2.2 \mathrm{Wm}^{-2}$ or a decrease in the solar constant of $9.4 \times 10^{-3} \%$. Neither of those changes are obtainable by changes in solar irradiance alone (Table 2). However, significant solar modulation of climate change within the two steady states, glacial-inter-glacial, can be obtained. Neglecting the increased positive feedback during a Little Ice Age, which we estimate to be only $\approx 10 \%$, a peak-to-peak change of $0.6^{\circ} \mathrm{C}$ (Table 2) explains most, if not all, of the Holocene temperature variation. The same change in solar irradiance, $2.4 \%$, would produce a peak-to-peak variation of $1.4^{\circ} \mathrm{C}$ at $18 \mathrm{ka}$. Figure 3 illustrates the increased variability of climate during the ice ages and decreased variability at present and during an ice-free climate.

The evidence that the recent warming event approaches or perhaps exceeds past events sets limits on natural variability during the Holocene but we must keep in mind that warming since the Little Ice Age is the combined effects of increased solar activity and greenhouse forcing. According to Hansen \& Lacis (1990), greenhouse forcing to 1989 was $2.04 \mathrm{Wm}^{-2}$, to which must be added our estimated solar forcing of $0.58 \mathrm{Wm}^{-2}$ (Table 2) or about $2.6 \mathrm{Wm}^{-2}$ total. This forcing at equilibrium, assuming the validity of the climate sensitivity of $1^{\circ} \mathrm{C} / \mathrm{Wm}^{-2}$, would yield an increase of $2.6^{\circ} \mathrm{C}$ since the Maunder Minimum. 
However, heat is transported to the mixed layer of the ocean and from there to the deep sea resulting in a long lag time. From their three-dimensional (3D) model, Hansen et al. (1984) estimated "the time for the global area-weighted mixed layer temperature to reach 63 percent of its equilibrium response in 124 years" (p. 156). The 124-year e-folding time is applicable for the high climate sensitivity of $1^{\circ} \mathrm{C} / \mathrm{Wm}^{-2}$. If we divide the $0.6^{\circ} \mathrm{C}$ (Table 2) equilibrium temperature increase equally between warming after the Maunder Minimum and additional warming during the Modern Solar Maximum, we calculate that $25 \%$ of the current warming of $0.5^{\circ} \mathrm{C}$ is from solar forcing and $75 \%$ is the result of greenhouse gas forcing. The temperature rise following the Maunder Minimum would attain its equilibrium value of $0.3^{\circ} \mathrm{C}$ to which $0.125^{\circ} \mathrm{C}$ must be added from the warming due to the current solar maximum. The resultant $0.425^{\circ} \mathrm{C}$ would then constitute a little more than half of the $0.8^{\circ} \mathrm{C}$ warming since the Maunder Minimum.

Our argument, thus far, has been based upon the high climate sensitivity of $1^{\circ} \mathrm{C} / \mathrm{Wm}^{-2}$. As a result of uncertainties in the feedbacks, the range of possible climate sensitivities lies between $0.5^{\circ} \mathrm{C} / \mathrm{Wm}^{-2}$ and $1.25^{\circ} \mathrm{C} / \mathrm{Wm}^{-2}$ (Hansen \& Lacis 1990). The e-folding time is also a function of the feedbacks $\left(\sum f_{i}\right)$. For the lowest value of climate sensitivity, $0.5^{\circ} \mathrm{C} / \mathrm{Wm}^{-2}$, the e-folding time is only about 40 years. This much shorter residence time slightly more than compensates for the lower greenhouse forcing climate sensitivity but the solar contribution falls to $13 \%$ of the current global warming. The total temperature rise since the Maunder Minimum becomes $0.65^{\circ} \mathrm{C}$, of which only $33 \%$ is due to solar forcing.

It is of interest to apply this analysis to pre-anthropogenic climate change. For this, we take predicted temperature change between the Medieval Solar Maximum (ad 11001250) and the immediately following Wolf Minimum (ad 1250-1350). We assume, as above, that the equilibrium warming and subsequent cooling would each be $0.3^{\circ} \mathrm{C}$. The predicted temperature fall must be calculated from the e-folding time of 124 years. It would be $\approx 0.4^{\circ} \mathrm{C}$. This global change is not great but would be observable in climatically sensitive regions using appropriate paleoclimate indicators. It would probably be below detection levels in other regions. If the climate sensitivity is $0.5^{\circ} \mathrm{C} / \mathrm{Wm}^{-2}$, the temperature decrease would only be $\approx 0.3^{\circ} \mathrm{C}$ but probably still observable. At high latitudes and at high elevations, the temperature might change by $1^{\circ} \mathrm{C}$ as compared to a $2^{\circ} \mathrm{C}$ warming during the current global warming event. There remains the possibility of greater cooling during prolonged periods of intense solar minima such as the Little Ice Ages (ad 12501850), for example. To completely account for Holocene temperature changes, however, it seems that all permissible solar and terrestrial factors must be maximized.

\section{Conclusions and summary remarks}

1. Pleistocene climate alternates between two steady states, glacial and interglacial, separated by transitional episodes. Climatic fluctuations around steady state are greater during glacial epochs than interglacial epochs by about a factor of three to four as observed in oxygen isotope stratigraphy.

2. Regional temperature changes are much more variable than and should not be confused with global temperature change. Since climatic events like the Little Ice Age, Medieval Warm Epoch and Altithermal were originally defined based upon paleoclimatic and historical events from Northern Europe and the North Atlantic regions, there has been a tendency to exaggerate global temperature changes during the Holocene.

3. Present global warming can serve as a frame of reference in evaluating Holocene global temperature changes from paleoclimate records within climatically sensitive regions such as high-latitude and high-altitude continental areas. Such comparison strongly 
suggests that global temperature change did not exceed $\pm 0.5^{\circ} \mathrm{C}$ during the last $10 \mathrm{ka}$ or $\pm 2.0^{\circ} \mathrm{C}$ during the last glacial period.

4. The Sun is a low frequency harmonic oscillator with solar activity fundamental frequencies of $1 / 2120 \mathrm{yr}, 1 / 212 \mathrm{yr}, 1 / 87 \mathrm{yr}$ and $1 / 11 \mathrm{yr}$ plus harmonics. The $1 / 2120$ yr cycle includes two phases, episodes lasting 600 years during which the century-scale variation includes pronounced minima such as the Maunder Minimum separated by 1500 year episodes of high and more chaotic activity.

5. The Sun in one of a family of Sun-like stars most of which have cycles of brightness similar to the Sun's. These Sun-like stars vary in brightness up to four times the variation in brightness of the Sun. Some of the Sun-like stars are in quiescent states similar to the Sun during the Maunder Minimum (Baliunas \& Jastrow 1990; Lockwood et al. 1992).

6. Lean et al. (1992) suggest that, during a solar minimum, the Sun decreases in brightness by $2.4 \%$ relative to the present Sun similar to the average variation of the non-cycling stars (Table 2).

7. Based on the 3D GCM analysis of Hansen et al. (1984), decreases in irradiance of $2.4 \%$ during solar minima relative to the present Sun would result in decrease of equilibrium global temperature by from $0.3^{\circ} \mathrm{C}$ to $0.6^{\circ} \mathrm{C}$ during the present interglacial and $0.9^{\circ} \mathrm{C}$ to $1.4^{\circ} \mathrm{C}$ during the last glacial maximum at $18 \mathrm{ka}$.

8. Applying paleoclimatic restraints on global temperature and using the 3D GCM analysis of Hansen et al. (1984) with a climate sensitivity of $1^{\circ} \mathrm{C} / \mathrm{Wm}^{-2}$, we estimate that global temperature increased by $\approx 0.3^{\circ} \mathrm{C}$ following the Maunder Minimum and more than $0.1^{\circ} \mathrm{C}$ of the $0.5^{\circ} \mathrm{C}$ of the current global warming since the late 19th Century would be the result of increased solar irradiance during the Modern Solar Maximum. Thus, about $50 \%$ of warming since the Maunder Minimum would be the result of increase solar activity. If the lowest estimated climate sensitivity is assumed $\left(0.5^{\circ} \mathrm{C} / \mathrm{Wm}^{-2}\right)$, the solar contribution would be only about $33 \%$.

9. A climate sensitivity of $1^{\circ} \mathrm{C} / \mathrm{Wm}^{-2}$ requires that, if no more greenhouse gases were released to the atmosphere, global average temperature would continue to increase by $2.6^{\circ} \mathrm{C}$ due $\approx 20 \%$ to solar activity and $\approx 80 \%$ to the effect of greenhouse gases. Such an increase would be unprecedented during the last $2 \mathrm{Ma}$. With inevitable further release of greenhouse gases, global climate would tend towards an ice-free globe held in check only be the large thermal inertia of the global oceans and polar ice.

10. Assuming the validity of the astrophysics-solar physics analysis of Lean et al. (1992), changes in solar irradiance cannot result in a change from interglacial to glacial as suggested by Opik (1965). However, the century-scale and millennial changes in solar activity can account for much of the climate fluctuations around the glacial and interglacial steady states due to the existence of strong positive feedbacks.

11. In order to completely explain Holocene global temperature changes by solar forcing, all terrestrial and solar factors must be optimized. Since this is unlikely, we conclude that solar forcing of pre-anthropogenic global climate change is a significant and perhaps dominant factor, but other processes must also be significant.

12. Added note: The Vostok Antarctica core demonstrates relative climate stability during the present interglacial (Holocene) and also the penultimate (Eemian) interglacial (Dansgaard et al. 1993). The apparent instability during the Eemian suggested by the recent GRIP and GISP cores from Greenland (ibid.) appears to be caused by layer thinning and deformation rather than climate instability (e.g., Grootes et al. 1993).

Acknowledgments. We are grateful to Professor Charles Sonett for the use of his computer facilities and programs for power spectral analysis and for valuable advice. We also thank Dr. Thomas Crowley and James Hansen for their helpful comments. 
This work was supported by NSF Grants ATM-8919535, EAR-9203383 and the State of Arizona.

\section{REFERENCES}

Baliunas, S. \& JASTROW, R. 1990 Evidence for long-term brightness changes of solar-type stars. Nature 348, 520-523.

Barron, E. J. \& Washington, W. M. 1984 The role of geographic variables in explaining paleoclimate results from Cretaceous climate model sensitivity studies. J. Geophys. Res. 89, 1267-1279.

Beltrami, H., Jessup, A. M. \& Mareschal, J.-C. 1992 Ground temperature histories in eastern and central Canada from geothermal measurements: evidence for climate change. Paleogeogr., Paleoclimatol., Paleoecol. (Global Planetary Section) 98, 167-184.

Boden, T. A., Sepanski, R. J. \& Stoss, F. W. (eds.) 1991 Trends '91: A Compendium of Data on Global Change. Pub. No. ORNL/CDIAC-46, ESD Pub. No. 3746, Carbon Dioxide Information Center, Oak Ridge, TN, pp. 665.

Bradley, R. S. 1985 Quaternary Paleoclimatology: Methods of Paleoclimate Reconstruction. Allen and Unwin, Boston, USA. pp. 472.

Cook, E., Bird, T., Barbetti, M., Buckley, B., D'Arrigo, R. \& Francey, R. 1992 Climatic change over the last millennium in Tasmania reconstructed from tree-rings. The Holocene 2, 205-217.

Crowley, T. J. \& North, G. R. 1991 Paleoclimatology. Oxford Univ. Press, New York, pp. 339.

Damon, P. E. \& JiRIKowic, J. L. 1992a The Sun as a low-frequency harmonic oscillator. Radiocarbon 34, 199-205.

Damon, P. E. \& Jirikowic, J. L. 1992b Radiocarbon evidence for low frequency solar oscillations. In Rare Nuclear Processes (ed. P. Povinec). pp. 177-202. Proceedings of the 14th Europhysics Conference on Nuclear Physics, World Scientific Publishers, Singapore.

Damon, P. E. \& SonetT, C. P. 1991 Solar and terrestrial components of the atmospheric ${ }^{14} \mathrm{C}$ variation spectrum. In The Sun in Time (ed. C. P. Sonett, M. S. Giampapa \& M. S. Matthews). pp. 361-388. Univ. of Arizona Press, Tucson, AZ, USA.

DansGaARD, W. 1964 Stable isotopes in precipitation. Tellus 16, 436-468.

Dansgaard, W., Clausen, H. B., Gundestrup, N., Hammer, C. U., Johnsen, S. J., KristensdottiR, P. M. \& Reeh, H. 1982 A new Greenland ice core. Science 218, 12731277.

EdDy, J. A. 1977 Climate and the changing Sun. Climatic Change 1, 173-190.

EPSTEIN, S. 1959 The variations of the ${ }^{18} \mathrm{O} /{ }^{16} \mathrm{O}$ ratio in nature and some geologic implications. In Researches in Geochemistry (ed. P. H. Abelson). pp. 217- 240. John Wiley and Sons, New York, USA.

FAIRBANKs, R. G. 1989 A 17,000-year glacio-eustatic sea level record: influence of glacial melting rates on the Younger Dryas event and deep-ocean circulation. Nature 342, 637-642.

Folland, F. P., Karl, T. \& Barnett, T. P. 1990 Observed climate variations and change. In Climate Change (The IPCC Scientific Assessment) (ed. J. T. Houghton, G. J. Jenkins \& J. S. Ephraums). pp. 195-238. Cambridge Univ. Press.

Graybill, D. A. \& Shiyatov, S. G. 1992 Dendroclimatic evidence from the northern Soviet Union. In Climate Change since a.d. 1500 (ed. R. S. Bradley \& P. D. Jones). pp. 393-414. Routledge, London.

Grootes, P. M., Stuiver, M. \& White, J. M. C. 1983 A long isotopic record at the Greenland Summit. EOS 74(43), 78 (abstract).

HANSEN, J. E. \& LACIS, A. A. 1990 Sun and dust versus greenhouse gases: an assessment of the relative roles in global climate change. Nature 346, 713-719.

Hansen, J., Lacis, A., Rind, D., Russell, G., Stone, P., Fung, I., Ruedy, R. \& Lerner, J. 1984 Climate sensitivity: analysis of feedback mechanisms. In Climate Processes and 
Climate Sensitivity (ed. J. E. Hansen \& T. Takahashi). pp. 130-163. Geophys. Monograph 29, Maurice Ewing, 5, Amer. Geophys. Union, Washington, D.C., USA.

Hanson, K., MAUL, G. A. \& KarL, T. R. 1989 Are atmospheric "greenhouse" effects apparent in the climate record of the contiguous U.S. (1895-1987)? Geophys. Res. Lett. 16, 49-52.

Hasenrath, S. \& Kruss, P. D. 1992 Greenhouse indicators in Kenya. Nature 355, 503-504.

INNES, J. L. 1992 High-altitude and high-latitude tree growth in relation to past, present and future global climate change. The Holocene 1, 168-173.

JACOBY, G. C. \& D'ARrigo, R. 1989 Reconstructed Northern Hemisphere annual temperature since 1671 based on high-latitude tree-rings from North America. Climatic Change 14, 3959.

JIRIKowIC, J. L. \& DAMON, P. E. 1994 The medieval solar activity maximum. Climatic Change, in press.

Johnsen, S. J., Dansgaard, W., Clausen, H. B. \& Langway, C. C. JR. 1972 Oxygen isotope profiles through the Antarctic and Greenland ice sheets. Nature 235, 429-434.

KAKUTA, S. 1992 Surface-temperature history during the last 1000 years near Prudhoe Bay: applying control theory to the inversion of borehole temperature profiles. Paleogeogr., $\mathrm{Pa}$ leoclimatol., Paleoecol. (Global Planetary Section) 98, 225-244.

KASER, G. \& Noggler, B. 1991 Observations on Speke Glacier, Ruwenzei Range, Uganda. Jour. of Glaciology 37, 313-318.

Lachenbruch, A. \& Marshall, B. V. 1956 Geothermal evidence from permafrost in the Alaska Arctic. Science 234, 689-696.

Lean, J., Stumanich, A. \& White, O. 1992 Estimating the Sun's radiative output during the Maunder Minimum. Geophys. Res. Lett. 19, 1591-1594.

LOcKwood, G.W. 1994 Irradiance variations of stars. In The Sun as a Variable Star: Solar and Stellar Irradiance Variations (ed. J.M. Pap, C. Frohlich, H.S. Hudson \& S.K. Solanki). Cambridge Univ. Press, in press.

Lockwood, G. W., Skiff, B. A., Baliunas, S. L. \& Radick, R. R. 1992 Long-term solar brightness changes estimated from a survey of Sun-like stars. Nature 360, 653-655.

Mcintyre, A., Moore, T. C. \& 34 other Climap Project Members 1976 The surface of the ice-age Earth. Science 191, 1131-1144.

OPIK, E. J. 1965 Climatic change in cosmic perspective. Icarus 4, 289-307.

Rothlisberger, F. 198610000 Jahre Gletschargeshicte der Erde. Aarau, Verlag Sauerlander, 416 'pp.

Schmidt, B. \& Gruhle, W. 1988 Klima, Radiokohlenstoffgehalt und Dendrochronologie. Naturwissenshaftliche Rundschau 5, 177-182.

Shen, P. Y. \& BECK, A. E. 1992 Paleoclimate change and heat flow density inferred from temperature data in the Superior Province of the Canadian Shield. Paleogeogr., Paleoclimatol., Paleoecol. (Global Planetary Section) 98, 143-165.

SonETT, C. P. 1982 Sunspot time series: spectrum from square law modulation of the Hale Cycle. Geophys. Res. Lett. 9, 1313-1316.

Stuiver, M. \& Braziunas, T. F. 1989 Atmospheric ${ }^{14} \mathrm{C}$ and century-scale solar oscillations. Nature 338, 405-408.

Stuiver, M \& Reimer, P. J. 1993 Extended ${ }^{14} \mathrm{C}$ data base and revised CALIB $3.0{ }^{14} \mathrm{C}$ age calibration program. Radiocarbon 35, 215-230.

Stuiver, M., Braziunas, T. F., Becker, B. \& Kromer, B. 1991 Climatic, solar, oceanic, and geomagnetic influences on late-glacial and Holocene atmospheric ${ }^{14} \mathrm{C} /{ }^{12} \mathrm{C}$ change. Quaternary Research 35, 1-24.

Tномson, D. J. 1990 Quadratic-inverse spectrum estimates: applications to palaeoclimatology. Trans. Roy. Soc. London A332, 539-597.

Thомpson, L. G. 1991 Private communication, Workshop on the Medieval Warm Epoch, Tucson, Arizona.

Thompson, L. G., Mosley-Thompson, E., Davis, M. E., Bolzan, J. F., Dai, J., Yao, 
T., Gunderstrup, N., Wu, X., Klein, L. \& XIE, Z. 1989 Holocene-Late Pleistocene climatic ice core records from Qinghai-Tibetan Plateau. Science 246, 474-477.

WANG, K., Lewis, T. J. \& Jessup, A. M. 1992 Climatic changes in eastern and central Canada inferred from deep borehole temperature data. Paleogeogr., Paleoclimatol., Paleoecol. (Global Planetary Section) 98, 129-141.

Wang, W. C., Dudek, M. P., Liang, X. Z. \& Kiehl, J. T. 1991 Inadequacy of effective $\mathrm{CO}_{2}$ as a proxy in simulating the greenhouse effect of other radiatively active gases. Nature $\mathbf{3 5 0}$, 573-577.

Willson, R. C. \& Hudson, H. S. 1988 Solar luminosity variations in solar cycle 21. Nature 332, 810-812.

Willson, R. C. \& Hudson, H. S. 1991 The Sun's luminosity over a complete solar cycle. Nature 351, 42-44. 